\title{
Proximate and Acute Toxicity Profile of Vitex doniana (Black Plum) Fruit
}

\author{
C. Imoisi ${ }^{1 *}$, J.U. Iyasele ${ }^{1}$ and S.E. Okhale ${ }^{2}$ \\ ${ }^{1}$ Department of Chemistry, University of Benin, Benin City, Nigeria. P.M.B.1154, Benin City, Nigeria. \\ ${ }^{2}$ Departments of Medicinal Plant Research and Traditional Medicine, National Institute for \\ Pharmaceutical Research and Development (NIPRD), Garki, Abuja, Nigeria. \\ *Correspondents Author: imoisi.chinyere@gmail.com, Tel: +2347030746386 \\ Received 18 January 2021; accepted 20 March 2021, published online 30 March 2021
}

\begin{abstract}
The fresh fruits of Vitex doniana sweet were collected from several randomly selected trees in a farm site in Uromi metropolis, Esan North-East Local Government Area of Edo state and then processed into an extract in form of syrup. The proximate composition and acute toxicity profile of Vitex doniana sweet fruit were investigated to ascertain its safety and nutritional capability. Analysis of the fruit showed it to be a highly nutritious food containing moisture of about, $9.90 \%$, ash content: $21.5 \%$, fat: $0.75 \%$, fiber: Not detected (ND), protein: $0.006 \%$ and carbohydrate: $67.84 \%$. Twenty mice were randomized based on body weight into five groups of four mice each. Three mice in each group were given syrup volumes of $100,200,300,400$ and $500 \mathrm{mg} / \mathrm{ml}$ respectively, corresponding to $1000,2000,3000,4000$ and 5000 $\mathrm{mg} / \mathrm{kg}$ doses. In contrast, mice in the control group received potable water $(10 \mathrm{~mL} / \mathrm{kg})$. The mice in all the groups were observed closely for mortality, toxicity signs and abnormalities in gross behaviour at 15 min, $30 \mathrm{~min}, 1,2,4$ and $8 \mathrm{~h}$, and then daily for 14 days. Based on the model used, the fruit was acutely safe in mice, since no death was observed within 24 hours after oral treatment and on extrapolation gave a high predictive value in humans. The $\mathrm{LD}_{50}$ value of black plum fruit was also found to be greater than $5000 \mathrm{mg} / \mathrm{kg}$. Therefore, Vitex doniana fruit should be considered a source of edible syrup bearing in mind the safety, quantity and variety of nutrients it contains.
\end{abstract}

Keywords: Acute toxicity, proximate composition, $\mathrm{LD}_{50}$ value, Safety, Vitex doniana

\section{Introduction}

The herbal remedy is garnering attractiveness in emerging countries. Herbal medications are time and again thought not to be hurtful since they are natural and free of negative consequence [1]. This surge in acceptance and the dearth of methodical studies on their effectiveness and safety have raised apprehensions concerning the therapies' harmfulness and adverse effects [2]. Study attention has concentrated on countless herbs that retain hypolipidemic, antiplatelet, antitumor, or immune-stimulating characteristics that might be beneficial adjuncts in facilitating to decrease the threat of cancer and cardiovascular illness [3]. Presently, there is an unending world-wide green uprising that is chiefly premised on the conviction that herbal medicines are benign and less harmful to the human body than synthetic drugs [4]. Herbal drug shows essential role in sustaining the wellbeing and affluence of men folk. The bulk of the world's populace utilizes herbal treatments. The World Health Organization (WHO) rumors that about 21,000 vegetation have been utilized for therapeutic purposes [5]. Herbs have stood the investigation of time for their welfare, efficiency, social suitability and marginal side special effects [6]. With increasing stress on improving traditional herbal food resources in Nigeria, there is the requisite for improved understanding of available flowers plus the severally underutilized classes. Black plum is a vegetal extensively used by numerous societies in Nigeria for countless purposes, and manufacture of wine and jam. Ready mature black plum fruits for diet usage, is usually gathered from the ground instead of plucked [7]. Vitex doniana signifies some of our abandoned underutilized forestry assets. Although major research on the health benefits of plant-rich diets has emphasized established vitamins, the current data are controversial, and the drive towards identifying more constituents and plant food sources continues [8]. In addition, the economic importance of Vitex doniana is yet to be exploited to its maximum regardless of the documented uses. Black plum of the genus verbanacae is a shrub produce that breeds in open woodland and grassland regions of hot Africa; it is the most predominant of the Vitex species in West Africa. It yields fruits that are like plum, sweet-smelling and fit for human consumption. The fruit is green when matured and transforms to dark brown when completely ripe, with the flesh surrounding a hard stone encompassing 1 to 4 seeds. It is a grassland species and hence can originate in northern, western as well as eastern Nigeria. Flowers and other components of natural sources have been useful all over the world for mortal and animal 
health maintenance for a very long time. This is mainly in Africa, where underdevelopment and dearth have made a massive proportion of the populaces depend more or less on traditional therapeutic practices and folkloric application of vegetation [9].

Quite a lot of researchers have displayed the efficiency of most traditional herbal therapies. One of such vegetal popular for it widespread usage in Africa natural folklore is $V$. Doniana Sweet. The herb is indigene to Botswana, Nigeria, Kenya, Ethiopia, Namibia, Lesotho, Senegal, Niger, South Africa, Somalia, Tanzania, Sudan, Zambia and Uganda. It is locally known as dinya (Hausa), Vitex (English), oori-nla (Yoruba) and ucha koro (Igbo) [10]. In traditional medicine, several portions of the vegetables are applied as medication for communicable conditions [11]. For instance the leaf, the bark, dried and fresh fruit serve as ingredients in many preparations to treat or heal diseases including conjunctivitis, headache, stiffness, measles, rash, fever, chickenpox, hemiplegia, respiratory diseases, ankylostomiasis, rachitis, gastro-intestinal disorders, jaundice, kidney troubles, leprosy, liver diseases, bleeding after childbirth and diarrhea [11]. Vitex doniana is a crucial indigenous fruit or leafy vegetable in Africa [12]. The blackish extract developed by steaming the bark, foliage, root and/or fruits is used as ink and dye for apparels [12]. In the light of the above, this research aims to connect scientific outcomes with many of these therapeutic uses to draw more research attention to herb in trending lead/hit scenarios in drug finding.

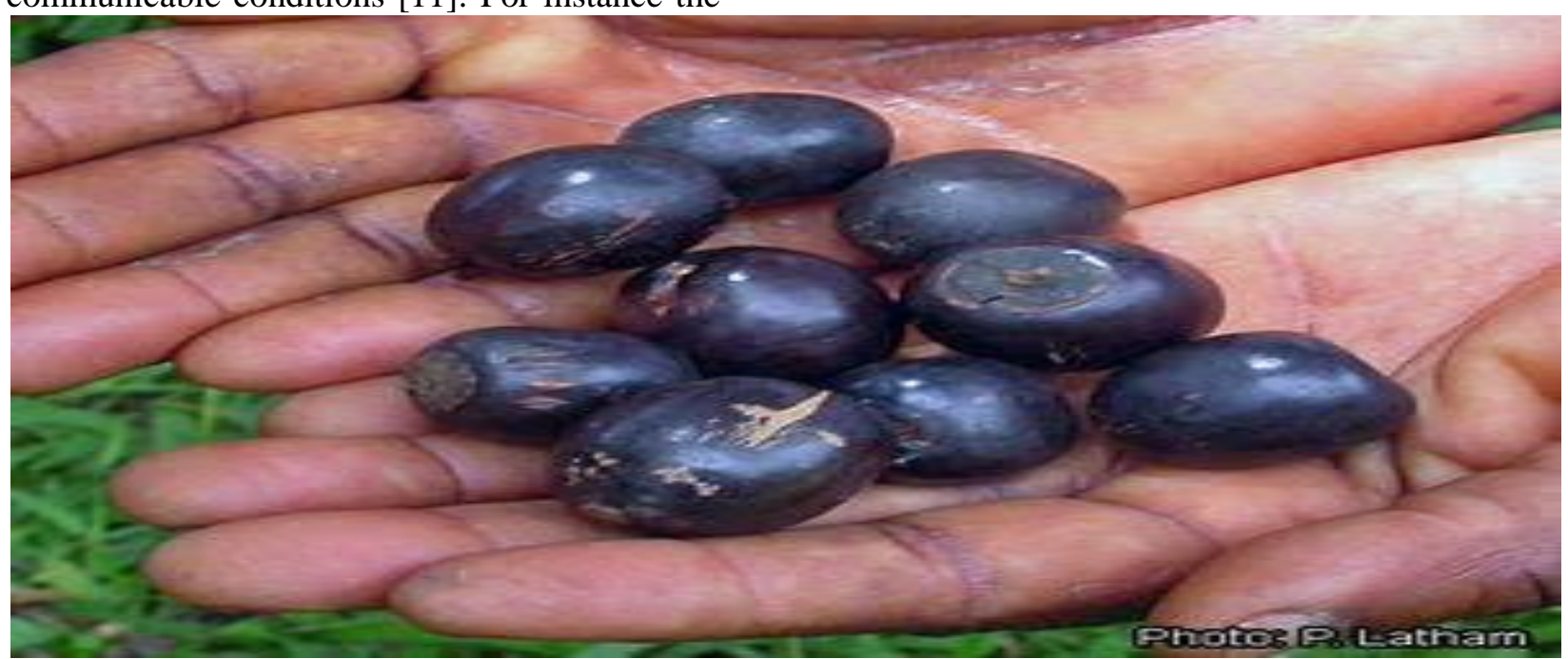

Figure 1: Ripe matured Vitex doniana sweet fruit

\section{Materials and Methods \\ Chemicals}

All the chemicals/reagents used in the current research were of analytical grade and were purchased from Sigma Chemical Company (St. Louis, Missouri, USA).

\section{Plant Collection and Identification}

The collection was done using the method described by Aiwonegbe et al. [13]. The fresh fruits of black plum (Vitex doniana) (purpleblack) (Fig. 1) (1500 fruits) weighing 3kg were collected by picking ripe fruits that fell on the ground from several randomly selected trees in a farm site in Uromi, Esan-North East Local Government Area of Edo state on $28^{\text {th }}$ August, 2018 during the fruiting season (June-October, annually). The fruits were stored at (ambient temperature, $85 \%$ Relative Humidity). The fruits were $2.8-3.2 \mathrm{~cm}$ in length, $1.2-1.4 \mathrm{~cm}$ in width and contained one hard conical seed each which is about 1.5-2.0 cm long and 1.0-1.2 cm wide. The quartering method [14] was used to select fruits for analysis. The plant was identified and authenticated by the Ethnobotanist in the Department of Medicinal Plant Research and Traditional Medicine (MPR\&TM) of the National Institute for Pharmaceutical Research and Development (NIPRD) Abuja, Nigeria. A reference voucher specimen number NIPRD/01/03/CCPF/384/3 was deposited at the herbarium of (NIPRD), Idu Industrial Area, Abuja.

\section{Extraction of the Syrup from Vitex doniana} Fruit

Extraction was done using a method modified by Aiwonegbe et al. [13]. The fruits were kept under ambient temperature in the laboratory. The fruits were sorted to select the fresh ones and then cleansed to remove sand and other debris. After that, portable water was used for 
washing the fruit pulp, and the thin epicarp was removed. The fruits were then milled through a $90 \mu \mathrm{m}$ sieve to press out the succulent mesocarp and separate the stony seed from the pericarp. In a waring blender for a few seconds, the fruit pulp $(1000 \mathrm{~g})$ was blended with $1400 \mathrm{ml}$ of distilled water in a Waring blender for 10 seconds. The syrup which weighed $1.5 \mathrm{~kg}$ was immediately bottled in an air-tight container. The syrup was stored in the refrigerator at $4{ }^{\circ} \mathrm{C}$ before analysis.

\section{Proximate Analysis}

The proximate composition of the ash, moisture, crude protein, carbohydrate, crude fiber and fat content of the sample (syrup) was determined using standard methods AOAC [15].

\section{Determination of Moisture Content}

By using oven-drying method, the moisture content was ascertained. Through using of meter balance, desiccated and uncontaminated Petridishes were weighing up and their individual weights noted $\left(\mathrm{W}_{1}\right)$. Into the dishes $\left(\mathrm{W}_{2}\right)$, about $5 \mathrm{~g}$ of the syrup was weighed spreading as much as imaginable. The Petri-dishes in which the sample was present was moved into the heating chamber kept at $105{ }^{\circ} \mathrm{C}$ and dried out for about 3 hours. Inorder to cool, once 3 hours they were moved to the desiccator and weigh up. Until a constant weigh $\left(\mathrm{W}_{3}\right)$ was obtained, this process was continued. The percentage moisture content was taken to be the loss in weight during drying in percentage.

$\%$ moisture $=$ weight lost due to drying $\mathrm{x} 100$

$$
\begin{aligned}
& \text { Sample weight taken } \\
= & \frac{\mathrm{W}_{2}-\mathrm{W}_{3}}{\mathrm{~W}_{2}-\mathrm{W}_{1}} \times 100
\end{aligned}
$$

\section{Ash Determination}

About $1 \mathrm{~g}$ of the syrup was weigh up into dried, sparkling pre-weighed crucibles with cap $\left(\mathrm{W}_{1}\right)$. Using flame (lid remove), the organic matter was burned off till the entity converted to char. Thereafter, the crucibles were at that time moved to the muffle furnace set at $550{ }^{\circ} \mathrm{C}$ (lid removed). Charring was did not stop til a white or grey ash was gotten. In a desiccator the crucibles were then cool and reweighed $\left(\mathrm{W}_{2}\right)$

$\%$ Ash $=\mathrm{W}_{2}-\mathrm{W}_{1} \times 100$

\section{Crude Fat Determination}

Cleaned, dry thimble was weighed up as $\left(\mathrm{W}_{1}\right)$ and $5 \mathrm{~g}$ oven dry syrup was put and also reweighed $\left(\mathrm{W}_{2}\right)$. Up to $3 / 4$ of the flask, round bottom flask was occupied with petroleum ether (b.pt $40-60{ }^{\circ} \mathrm{C}$ ). Soxhlet extractor was secure with a reflux condenser and attuned to the high temperature source so that the solvent gently boils. The sample plus the thimble were implanted into the soxhlet apparatus and under reflux for over 6 hours; extraction was carried out with petroleum ether $\left(40-60{ }^{\circ} \mathrm{C}\right)$. For one hour, at $100{ }^{\circ} \mathrm{C}$ the thimble was then removed and taken into the oven and thereafter chilled in the desiccator and reweighed $\left(\mathrm{W}_{3}\right)$.

$\%$ fat $=$ weight of sample lost (extracted fat) $/$ weight of original sample $\mathrm{x}$ 100/1

$=\frac{\mathrm{W}_{2}-\mathrm{W}_{3}}{\mathrm{~W}_{2}-\underline{\mathrm{W}}_{1}} \times 100$

\section{Crude Protein Determination}

Into the micro kjeldahl digestion flask, about $1 \mathrm{~g}$ of the syrup was weighed and one selenium catalyst tablet and $15 \mathrm{ml}$ of concentrated $\mathrm{H}_{2} \mathrm{SO}_{4}$ were added. Inside a fume cupboard, the mix was processed on a heater which electro-thermal till a clear solution was gotten. The container left to cool afterward the solution was watered down with purified water to $5 \mathrm{ml}$ and $50 \mathrm{ml}$ of this was moved into the apparatus used for distillation. 5 $\mathrm{ml}$ of $2 \%$ boric acid was pipetted into a $100 \mathrm{ml}$ the receiver flask and 4 droplets of methyl red indicator that was screened were put. To the digested sample, $50 \% \mathrm{NaOH}$ was continually added til the solution turned gloomy which showed that the solution had turned alkaline. Into the acid solution in the receiver flask with the conveyance tube beneath the level of acid, the distillation was carried out. The pink color solution of the receiver flask turned blue as distillation was going on, representing the occurrence of ammonia. Distillation was sustained til the content of the round bottom flask was nearly $50 \mathrm{ml}$ afterwards which the conveyance of the condenser was cleaned using purified water. The resultant solution in conical flask was then titrated with $0.1 \mathrm{MHCl}$.

$\%$ Nitrogen $=$ Titre value $\times 0.1 \mathrm{M} \mathrm{HCl} \times 0.014 \times$ $50 / 5$

Original weight of sample

$\%$ Protein $=\%$ Nitrogen $\mathrm{x}$ protein conversion factor

\section{Crude Fibre Determination}

In a separating funnel, $2.0 \mathrm{~g}\left(\mathrm{~W}_{1}\right)$ of the syrup was defatted with petroleum ether and put in a one litre conical flask; boiling $1.25 \%$ of $\mathrm{H}_{2} \mathrm{SO}_{4}$ of $200 \mathrm{ml}$ was put and for about 30 minutes boiled gently. A muslin cloth was utilized for the mixture filteration and properly cleaned with warm distilled water. With spatula the sample was scrapped again into the container and boiling $1.25 \% \mathrm{NaOH}$ of $200 \mathrm{ml}$ was added and for 30 minutes allowed to gently boil. Muslin cloth was used to filter and the remainder was thoroughly cleansed with warm distilled water 
and then cleaned again by means of $10 \% \mathrm{HCl}$, double with industrialized methylated spirit, at that point the remainder was again scrapped into a crucible, desiccated in the oven at $105{ }^{\circ} \mathrm{C}$. Cool in a dessicator and reweighed $\left(\mathrm{W}_{2}\right)$. In a muffle furnace, for 90 minutes the remainder was charred at $550{ }^{\circ} \mathrm{C}$, cooled in a desiccator and also reweighed $\left(\mathrm{W}_{3}\right)$.

$$
\% \text { Crude Fibre }=\underline{\mathrm{W}_{2}} \underline{\underline{\mathrm{W}_{1}}} \frac{\mathrm{W}_{1}}{\mathrm{~W}_{1}} \times 100
$$

\section{Carbohydrate Content Determination}

$\%$ Carbohydrate $=100-(\%$ Crude fibre $+\%$ Ash $+\%$ Crude protein $+\%$ Crude fat).

\section{Acute Toxicity Determination}

The extract's acute toxicity (syrup) was determined using standard methods OECD [16]. Swiss albino mice $(17-22 \mathrm{~g})$ were administered orally using an intra-gastric cannula. The syrup

\section{Results and Discussion}

Table 1: Proximate Composition of Vitex doniana Fruit Syrup

\begin{tabular}{ll} 
Parameter & Results obtain \\
\hline Moisture content ...... & $9.90 \pm 0.00$ \\
Ash content ........... & $21.50 \pm 1.41$ \\
Crude protein ......... & $0.006 \pm 0.00$ \\
Crude fibre ............ ND & ND \\
Crude fat ............ & $0.75 \pm 0.07$ \\
Carbohydrate content & $. .67 .84 \pm 1.06$ \\
\hline
\end{tabular}

The proximate composition analysis revealed important findings and results obtained as presented in table 1 . The data are Mean values \pm Standard deviation (SD) of three replicates. The moisture content of Vitex doniana fruit syrup was $9.90 \%$. The value $(9.90 \%)$ is somewhat greater than $4.68 \%$ and $3.5 \%$ stated for Vitex doniana fruit pulp and Detarium microcarpum respectively [18]. Therefore, the high moisture content of Vitex doniana syrup offers for the better activity of water-soluble enzymes and coenzymes necessary for metabolic activities of these plants [19]. Ash content estimates the overall mineral content of a foodstuff sample analyzed and had a value of $21.50 \%$. The great ash content indicates that the Vitex doniana syrup is rich in mineral elements.

Crude protein of Vitex doniana fruit syrup was $0.006 \%$, which is lesser than the $10.0 \%$ described by [22] for Vitex donina leaf and $8.24 \%$ for Vitex doniana fruit pulp. The crude fat of the edible portion of Vitex doniana fruit syrup was $0.75 \%$. Dreon et al. [20] showed that many drupes had high carbohydrate content subject to the maturity, fruit type and environment. Nonetheless, Vitex doniana fruit syrup had a value of $67.84 \%$. Carbohydrates are one of the was dissolved in water to obtain 100, 200, 300, 400 and $500 \mathrm{mg} / \mathrm{mL}$ concentrations. Twenty mice were randomized based on body weight into five groups of four mice each. Three mice in each group were given syrup volumes of 100, $200,300,400$ and $500 \mathrm{mg} / \mathrm{ml}$ respective syrup corresponding to 1000, 2000, 3000, 4000 and $5000 \mathrm{mg} / \mathrm{kg}$ doses respectively. Simultaneously, mice in the control group received potable water $(10 \mathrm{~mL} / \mathrm{kg})$. The mice in all the groups were closely observed for signs of toxicity at $15 \mathrm{~min}$, $30 \mathrm{~min}, 1,2,4$ and $8 \mathrm{~h}$, and then once daily for 14 days. Observations were recorded in the Malone and Robichaud [17] Hippocratic screening table. The observed results were recorded as a sign of toxicity/number of animals studied.

most important components in many foods, and digestible carbohydrates are considered an important energy source. The crude fiber was not detected in Vitex doniana fruit syrup than $(0.58 \%)$ reported for Vitex doniana fruit pulp [21]. Thus Vitex doniana fruit syrup is a poor source of dietetic fiber for human beings. The crude fiber assists to avert bowel problems, piles and constipation.

Phytotherapeutic substances are often viewed as harmless because they are natural [22]. Nonetheless, these substances have bioactive principles with a prospect to result in side effects [23]. Aside from giving a hint on the dosages that may perhaps be used in succeeding toxicity analysis, it can similarly make known the likely clinical signs caused by the constituent under examination. It is an advantageous parameter to examining the therapeutic index (i.e., $\mathrm{LD}_{50} / \mathrm{ED}_{50}$ ) of medications and xenobiotics [24].

Gross behavior study: No mortality was witnessed afterward administrating Vitex doniana fruit syrup at the dosages of 1000, 2000, 3000,4000 and $5000 \mathrm{mg} \mathrm{kg}^{-1}$ b.wt. This is a clue that the syrup has an insignificant level of toxicity after been administered orally. The behavioral signs of toxicity like CNS depression (Decreased motility, sedation, paralysis, alienation of environment, analgesia, anesthesia, loss of corneal reflex, and decreased respiratory frequency), CNS stimulation (Increased motility, tail erection, paw licking, increased respiratory frequency, tail biting, tremor, stereotype movements, convulsions and mouth scratching) and other effects like grooming, writhing, contortion, diarrhea, color, increased and decreased urination, 
aggressiveness, passivity, cyanosis, pallor and hyperemia were likewise looked out for. No signs of toxicity were detected in the treated or control sets. At a dose of 1000, 2000 and $3000 \mathrm{mg} / \mathrm{kg}$, the fruit syrup produced mostly CNS (central nervous system) stimulating signs such as tail erection, paw licking, mouth scratching and increased grooming within 1 hour after administration. However, in the 4000 and $5000 \mathrm{mg} / \mathrm{kg}$ group, these parameters were not obvious and grooming was most evident. The fruit syrup also appeared to cause abdominal distress characterized by contortion and abdominal writhing that lasted for up to 1 hour in 1000,2000 and $3000 \mathrm{mg} / \mathrm{kg}$ and 2 hours in 4000 and $5000 \mathrm{mg} / \mathrm{kg}$. No mortality was recorded in all mice throughout the 14 days duration of the study. 'Black plum fruit syrup' is acutely safe in mice based on the model used since none of the mice died within 24 hours after oral treatment. Abdominal distress may, however, be produced with high doses based on the model used. The model can predict toxicological effects, and on extrapolation, gives a high predictive value in humans [25]. The $\mathrm{LD}_{50}$ value is greater than $5000 \mathrm{mg} / \mathrm{kg}$ body weight [26]. According to Kennedy et al. [27], constituents with $\mathrm{LD}_{50}$ more significant than 5 $\mathrm{mg} / \mathrm{kg}$ by the oral route are considered non-toxic or virtually safe. Comparable outcomes were established for a particular oral dose administration of $P$. longifolia extracts in mice. This then means that $V$. doniana fruit syrup is assumed to be safe (non-toxic) as suggested by OECD [19]

Table 2: Results of the acute toxicity studies of Vitex doniana fruit syrup of $2000 \mathrm{mg} / \mathrm{kg}$ dose on mice

$$
\text { Activity PARAMETERS }
$$

TIME OF INJECTION 


\section{Conclusion}

The plant considered here could be perceived as a possible source of valuable medicines. Vitex doniana fruit should also be considered a source of edible syrup, and their cultivation should be encouraged as it is endorsed for constant usage for dietary purposes, bearing in mind the quantity and variety of nutrients it contains. The study also established that Vitex doniana fruit is hitherto an alternative path out of the nutritional "wilderness" currently experienced by several people in Nigeria and perhaps West Africa. Vitex doniana is exceptionally exploited conservatively for ethno medicinal reasons. The syrup of Vitex doniana drupe was discovered negligibly non-toxic after an oral acute toxicity study in mice was accomplished. Thorough experimental examination on chronic toxicity is vital for additional backing of this syrup as a medicine.

\section{Acknowledgement}

Special thanks go to the Department of Chemistry, University of Benin, Benin City and to Prof. J.U. Iyasele of the Department of Chemistry, University of Benin, Benin City for his impactful, insightful and invaluable contributions.

\section{References}

1. L.D.C. Lopes, F. Albano, G.A.T. Laranja, L.M. Alves and L.F.M. Silva (2000), Toxicological Evaluation by in vitro and in vivo assays of an aqueous extract prepared from Echinodorus macrophyllus leaves, Toxicol. Lett., 116, 189-198.

2. B. Saad, H. Azaizeh, V. Abu-Hijleh and S. Said (2006), Safety of traditional Arab herbal Medicine. Evidence-Based Complement, Altern. Med., 3, 433-439.

3. W.J. Craig (1999), Health-promoting properties of common herbs, Am. J. Clin. Nutr., 70, 491-499.

4. J. Parekh and S. Chanda (2006), In-vitro Antimicrobial activities of extracts of Launaea Procumbens Roxb. (Labiateae), Vitis vinifera L. (Vitaceae) and Cyperus rotundus L. (Cyperaceae), Afr. J. Biomed. Res., 9, 89-93.

5. L. Cathrine and N.P. Nagarajan (2011), Preliminary phytochemical analysis and antibacterial Activity of leaf extracts of Vitex leucoxylon, Int. J. Curr. Pharm. Res., 3, 71-73.

6. P. Chandan, V. Kumar, K.P. Kamthan, U.B. Singh, S.K. Srivastava and R.B. Srivastava (2011), Antioxidant and antimicrobial activity of ethanol and water extracts of Cymbopogonj warancusa leaves, J. Appl. Pharm. Sci., 1, 68-72.

7. R.N. Okigbo (2001), Mycoflora within black plum (Vitex doniana) sweet fruits, Fruits, 56, 85-92.

8. C.O. Ochieng and B.O. Nandwa (2010), Proximate composition, Phenolic Content and Antioxidant Activities of three black plum (Vitex $s p$.) fruits: Preliminary results, J. Food Technol., 8(3), 118-125.

9. A.P. Enzo (2006), Review article: Phytochemicals from Traditional Medicinal Plants used in Composition of the Pulverized root of Cissus quadrangularis, Bioresearch, 1, 63-68.

10. O. Ladeji, F.V. Udoh and Z. Okoye (2005), Activity of aqueous extract of the bark of Vitex doniana on uterine muscle response to drugs, Phytotherapy Research, 19, 804-806.

11. H.M. Burkill (2000), Useful Plants of West Tropical Africa, Royal Botanic Garden Kew, 5(2), 272-275.

12. D. Hyson (2002), Health Benefits of Fruits and Vegetable. Scientific overview for health Professionals produce for better health foundation, Washington D.C., 20.

13. A.E. Aiwonegbe, J.U. Iyasele and N.O. Izevbuwa (2018), Proximate Composition, Phytochemical and Antimicrobial Screening of Methanol and Acetone Extracts of Vitex doniana Fruit Pulp, Ife Journal of Science, 20(2), 207-212.

14. W. Hortwitz (1988), Sampling and preservation of sample for chemical examination, J. Assoc. Anal. Chem., 71, 224-247.

15. AOAC (2000). Official methods of analysis of AOAC International, 17th edn. AOAC International: Gaithersburg, MD, USA.

16. Organisation for Economic Cooperation and Development (OECD) (2008), Guidelines for the Testing of chemicals, No. 425. Adopted $3^{\text {rd }}$ October 2008.

17. M.H. Malone and R.C. Robichaud (1962), A Hippocratic screen for pure or crude drug Materials, Lloyd, 25, 320332.

18. C.V. Nnamani, H.O. Oselebe and A. Agbatutu (2009), Assessment of Nutritional Value of Three Underutilized Indigenous Leafy 
Vegetables of Ebonyi State, Nigeria, Afr. J. Biotech., 8(9), 2321-2324.

19. K. Iheanacho and A.C. Ubebani (2009), Nutritional composition of some leafy Vegetable Consumed in Imo-State, Nigeria, Journal of Application Science in Environment Management, 13, 35-38.

20. D.M. Dreon, K.M. Vranizan, M.A.A. Kraus and P.D. Wood (1990), Effect of Poly Unsaturated and Monosaturated fat on Plasma Lipoproteins, J. Am. Med. Assoc., 263, 2462.

21. M.A. Vunchi, A.N. Umar, M.A. King, A.A. Liman, G. Jeremiah and C.O. Aigbe (2011), Proximate, Vitamins and Mineral Composition of Vitex doniana (Black plum) fruit pulp, Nigeria Journal of Basic and Applied science, 19(1), 97101.

22. W.M. Gesler (1992), Therapeutic landscapes: Medical issues in light of the new cultural

Geography, Soc. Sci. Med., 34, 735746.

23. S. Bent and R. Ko (2004), Commonly used herbal medicine in the United States: A review, Am. J. Med., 116, 478-485.

24. H.P. Rang, M. Dale and J. Ritter (2001), Pharmacology. 4th Edn., Churchill Livingstone, New York.

25. J.D. Tugwood, L.E. Hollins and M.J. Cookerill (2003), Genomics and the search for Novel Bookmarkers in Toxicology, 8, 79-92.

26. C.N.J. Assob, L.F.H. Kamga, S.D. Nsagha, L.A. Njunda, F.P. Nde, A.E. Asongalem, J.A. Njouendou, B. Sandjon and B.V. Penlap (2011), Antimicrobial and toxicological Activities of five medicinal plants from Cameroon Traditional Medicine, BMC Complement Altern. Med., 11, 70.

27. G.L. Kennedy, R.L.J. Ferenz and B.A. Burgess (1986), Estimation of acute toxicity in rats by Determination of the approximate lethal dose rather than the LD50, J. Applied Toxicol., 6, 145-148. 